\title{
Assessment of Energy Intake and Energy Expenditure of Male Adolescent Academy-Level Soccer Players during a Competitive Week
}

\author{
Marc A. Briggs ${ }^{1, *}$, Emma Cockburn ${ }^{2}$, Penny L. S. Rumbold ${ }^{1}$, Glen Rae ${ }^{3}$, Emma J. Stevenson ${ }^{1}$ \\ and Mark Russell ${ }^{1}$ \\ Received: 12 August 2015 ; Accepted: 22 September 2015 ; Published: 2 October 2015 \\ 1 Department of Sport, Exercise and Rehabilitation, Faculty of Health and Life Sciences, \\ Northumbria University, Newcastle upon Tyne NE1 8ST, UK; \\ penny.rumbold@northumbria.ac.uk (P.L.S.R.); e.stevenson@northumbria.ac.uk (E.J.S.); \\ mark.russell@northumbria.ac.uk (M.R.) \\ 2 London Sport Institute, Middlesex University, London NW4 4BT, UK; e.cockburn@mdx.ac.uk \\ 3 MSK CATS, South Tyneside Foundation NE34 0PL, UK; glen.rae@stft.nhs.uk \\ * Correspondance: marc.a.briggs@northumbria.ac.uk; Tel.: +44-0-191-243-7913
}

\begin{abstract}
This study investigated the energy intake and expenditure of professional adolescent academy-level soccer players during a competitive week. Over a seven day period that included four training days, two rest days and a match day, energy intake (self-reported weighed food diary and 24-h recall) and expenditure (tri-axial accelerometry) were recorded in 10 male players from a professional English Premier League club. The mean macronutrient composition of the dietary intake was $318 \pm 24 \mathrm{~g} \cdot$ day $^{-1}\left(5.6 \pm 0.4 \mathrm{~g} \cdot \mathrm{kg}^{-1} \mathrm{BM}\right)$ carbohydrate, $86 \pm 10 \mathrm{~g} \cdot$ day $^{-1}$ $\left(1.5 \pm 0.2 \mathrm{~g} \cdot \mathrm{kg}^{-1} \mathrm{BM}\right)$ protein and $70 \pm 7 \mathrm{~g} \cdot$ day $^{-1}\left(1.2 \pm 0.1 \mathrm{~g} \cdot \mathrm{kg}^{-1} \mathrm{BM}\right)$ fats, representing $55 \% \pm 3 \%, 16 \% \pm 1 \%$, and $29 \% \pm 2 \%$ of mean daily energy intake respectively. A mean daily energy deficit of $-1302 \pm 1662 \mathrm{~kJ}(p=0.035)$ was observed between energy intake $(9395 \pm 1344 \mathrm{~kJ})$ and energy expenditure $(10679 \pm 1026 \mathrm{~kJ})$. Match days $(-2278 \pm 2307 \mathrm{~kJ}, p=0.012)$ and heavy training days $(-2114 \pm 2257 \mathrm{~kJ}, p=0.016)$ elicited the greatest deficits between intake and expenditure. In conclusion, the mean daily energy intake of professional adolescent academy-level soccer players was lower than the energy expended during a competitive week. The magnitudes of these deficits were greatest on match and heavy training days. These findings may have both short and long term implications on the performance and physical development of adolescent soccer players.
\end{abstract}

Keywords: energy intake; energy expenditure; soccer; adolescent; male

\section{Introduction}

Soccer is typically classified as a high-intensity, intermittent team sport comprised of two $45 \mathrm{~min}$ halves [1]. During a $90 \mathrm{~min}$ match, distances of 7-9 $\mathrm{km}$ have been reported for adolescents representing professional soccer academies [2-4]. In adult players of similar standard, match distances typically range between 9 and $13 \mathrm{~km}$ [5-7]. Similar match distances may insinuate comparable workloads between youth and adult populations. However, utilizing adult data to predict adolescent athletes' energy expenditure has been criticized and may not be directly comparable, due to the increased energy cost of exercise [8]. Energy balance is integral for adolescents to sustain optimal growth and development $[9,10]$, with additional nutritional intake required to offset the increased energy cost of high-level training and competition [11].

Research investigating soccer-specific nutritional intakes has been carried out in adult professional soccer [12-17]. However, a relatively limited amount of studies have investigated the 
nutritional intake of adolescent academy-level soccer players [18-22]. The findings of these studies, which have primarily investigated the habits of players from outside of the UK, have typically reported sub-optimal energy intake relative to estimates of energy expenditure [18,20-22]. In the only study to date to investigate dietary and activity regimes of adolescent soccer players in the UK, it was reported that dietary practices are inadequate to sustain the demands of training and competition, with a mean daily energy deficit of $-3299 \pm 729 \mathrm{~kJ}$ reported [23]. Although energy expenditure estimations utilized field-based methods, these equations were dependent upon subjective accounts of activity volume, recorded in self-reported training diaries. [18,20-23].

Assessing energy balance is reliant on the comparison of valid energy intakes against accurate methods of energy expenditure. Although doubly labelled water is deemed the gold standard when assessing energy expenditure [24], its complex approach may not be feasible for field-based researchers and practitioners. An alternative to this approach may be to adopt accelerometers, which have been demonstrated to elicit valid and reliable measures of physical activity in youth within free-living environments [25]. There are currently no studies, which have utilized accelerometry to assess energy expenditure, whilst also accounting for the potential under-reporting error of energy intake methods, within a full training and competition week in male adolescent Premier League academy-level soccer players in the UK.

Academy-level soccer players in the UK engage in mandatory training volumes of up to $20 \mathrm{~h}$ per week in accordance with the newly adopted Elite Player Performance Plan (EPPP) [26], with additional demands (school P.E.; county and/or national representation and other sporting commitments) independent of academy training, comprising training loads which are not comparable to full-time scholar soccer players. In order to better understand the dietary and activity habits of this population and to distinguish whether or not current dietary practices are adequate to meet the demands of training and match play and also growth and development, the aim of this study was to assess energy balance in male adolescent, academy-level soccer players over a seven day period that included four training days, one match day and two rest days. Based on previous studies, it was hypothesized that energy intake would be significantly less than energy expenditure.

\section{Experimental Section}

\subsection{Participants}

Ten male players (age: $15.4 \pm 0.3$ years; stature: $1.70 \pm 0.06 \mathrm{~m}$; body mass: $57.8 \pm 7.8 \mathrm{~kg}$ and Body Mass Index: $19.84 \pm 1.58 \mathrm{~kg} \cdot \mathrm{m}^{-2}$ ) who played for a Premier League soccer academy participated in the study. All participants were actively engaged in full training and competition, which over the course of the study consisted of four training days (two training sessions per day was classified as a heavy day and one session per day was classified as a moderate day), a match day and two non-training recovery days within a seven day period. Data collection period was during the second half of the competitive season (March), whereby participants were consistently engaged in $20 \mathrm{~h}$ of active training per week. Written informed consent was gained from both participants and their respective parents or guardians, once ethical approval was granted by the Faculty of Health and Life Sciences Research Ethics Committee at Northumbria University (approval number RE12-03-131775, 28th March 2013).

\subsection{Dietary Assessment}

Energy intake was recorded over a seven day period during the competitive season, using the combined method of self-reported weighed food diary, supplemented with 24-h recall [27]. Previous findings have demonstrated this method to be a valid alternative to current energy intake collection methods, when adjustment is made to offset under-reporting as previously described by Briggs et al. [27]. Seven day dietary data collection was seen as optimal to gain a sufficient amount of information whilst maintaining high compliance [28], and is indicative of previous studies [18,22,23]. 
Each participant was provided with a food diary and was asked to detail their weighed food intake, time of food consumption, preparation and cooking methods, and brand names. Provision of electronic portable scales facilitated weighing of all food items consumed. Prior to data collection, a series of practical workshops were delivered to all participants by the lead author in order to ensure that participants were familiar with the study procedures relating to energy intake. To coincide with the self-reported food diary each participant engaged in a 24-h recall interview on each day of the data collection period. Interviews were carried out using the two-pass method [29] whereby the overall eating events of the previous 24-h were reviewed to identify the main foods and beverages consumed; Secondly, the participants were prompted for more information such as condiments, brand names, additional food or drink items, how the foods were prepared and cooked and portion sizes if not provided in the food diaries.

Food diaries were cross-referenced with the respective 24-h recalls, supplementing any missing or additional information. Commercially available software was used to analyze energy intake (Microdiet version 2.8.5, Downlee Systems Limited, High Peak, UK). To ensure consistency, a single researcher, who was responsible for delivering the data collection familiarization workshops to the participants, performed all dietary analysis, as recommended by Deakin [30]. Total energy intake values were adjusted to accommodate for an under-reporting bias using a correction factor (Equation (1)) as previously identified by Briggs et al. [27].

$$
\begin{array}{r}
\text { Energy Intake : } y=1.0397 x-0.1064 \text { (where } y=\text { adjusted energy intake and } \\
x=\text { participants self }- \text { reported energy intake). }
\end{array}
$$

\subsection{Energy Expenditure Assessment}

Energy expenditure was calculated using accelerometry methods (ActiGraph GT3X+; ActiGraph, Pensacola, FL, USA) that demonstrate valid and reliable measures of physical activity and sedentary time in youth populations [25]. This accelerometer demonstrates high levels of inter-instrument reliability (ICC values: 0.97 to 1.00 for raw outputs and 0.97 to 0.99 for derived outputs, within free-living environments; [31]). The accelerometer was positioned above the anterior spine of the iliac crest in line with the anterior axillary line of the dominant hip as per the manufacturer's recommendations. The acceleration output was digitized by a 12-bit analogue-to-digital convertor at a user specific rate of $30 \mathrm{~Hz}$. Participants were instructed to wear the device for $24 \mathrm{~h}$ for each of the seven days except during exposure to water-based activities (e.g., swimming and bathing). MET intensity thresholds were adopted based on previous calibration studies [32-34] (Table 1). In addition cut points devised by Evenson et al. [32] were used as they exhibit significantly better accuracy than other published cut points [35] (Table 1).

Table 1. MET Intensity Threshold and Cut Points

\begin{tabular}{ccc}
\hline & MET Intensity Thresholds & Cut Points \\
\hline Sedentary Activity (SED) & $<1.5$ METs & $\leqslant 100$ \\
Light Physical Activity (LPA) & $\geqslant 1.5$ and $<4$ METs & $>100$ and \\
Moderate Physical Activity (MPA) & $\geqslant 4$ and $<6$ METs & $\geqslant 2296$ and $<4012$ \\
Vigorous physical Activity (VPA) & $\geqslant 6$ METs & $\geqslant 4012$ \\
\hline
\end{tabular}

Relevant METs and cut points were inserted to the ActiLife 6 Data Analysis Software (ActiGraph, Pensacola, FL, USA) accordingly, prior to energy expenditure calculations. In many research designs displaying energy expenditure in relation to METs is appropriate, however when comparing with energy intake, data expressed as $\mathrm{kJ}$ is more relevant and directly comparable. To calculate energy expenditure in $\mathrm{kJ}$, daily MET values were derived from the raw data accelerations and input in to 
a modified version of the equation devised by Ridley et al. [36] (Equation (2)), using Schofield's [37] prediction equation to estimate adolescent RMR (Equation (3)).

$$
\begin{aligned}
\text { Energy Expenditure }(\mathrm{kJ})= & \text { MET value } \times \text { adolescent } \mathrm{RMR}\left(\mathrm{kJ} \cdot \mathrm{kg}^{-1} \cdot \mathrm{min}^{-1}\right) \times \mathrm{kg} \\
& \text { body weight } \times \text { number of minutes activity performed }
\end{aligned}
$$

$$
\text { Resting Metabolic Rate }(\text { RMR })=17.686 \times \text { kg body weight }+658.2
$$

\subsection{Statistical Analysis}

Dietary intake data was considered reliable at $<20 \%$ when using the percentage of relative standard error (SEM $\div$ Mean) [23]. Seven day means for total energy intake (kJ), total energy expenditure $(\mathrm{kJ})$, energy deficit $(\mathrm{kJ})$ and macronutrients (\% total energy intake, $\mathrm{g}, \mathrm{g} \cdot \mathrm{kg}^{-1}$ ) were determined. A paired samples $t$-test was used to analyze differences in mean seven day energy balance and also differences in energy balance for different types of training/recovery days (heavy, moderate, rest) and match day. A one way (within-participants factor: energy deficit) repeated measures analysis of variance (ANOVA) was used to examine if energy deficit differed between days (heavy, moderate, rest and match day). A separate one way (within-participants factor: macronutrient intake) repeated measures ANOVA was used to examine if carbohydrate, protein and fat differed between days (heavy, moderate, rest and match day). Mauchly's test was consulted and Greenhouse-Geisser correction was applied if the assumption of sphericity was violated. Significant main effects were further investigated using multiple pairwise comparisons with Bonferroni confidence interval adjustment. All data are presented as mean $\pm S D$, with level of significance set at $p \leqslant 0.05$, using SPSS (Version 21; SPSS Inc., Chicago, IL, USA) for all analysis.

\section{Results}

Estimates of nutritional intake are considered reliable as relative standard error did not exceed $8 \%$ for any of the analyzed macronutrients.

\subsection{Macronutrients}

The mean daily macronutrient intakes, with a breakdown in relation to type of activity day are expressed in Table 2. The ANOVA revealed no significant main effect for carbohydrate $(F(3,27)=1.671, p=0.20)$, protein $(F(3,27)=0.883, p=0.46)$ and fat $(F(3,27)=1.963, p=0.14)$.

\begin{tabular}{|c|c|c|c|c|c|}
\hline Macronutrient & Heavy & Moderate & Rest & Match & Mean \\
\hline \multicolumn{6}{|c|}{ Protein } \\
\hline Per day $\left(\mathrm{g} \cdot\right.$ day $\left.^{-1}\right)$ & $93 \pm 29$ & $82 \pm 27$ & $96 \pm 22$ & $86 \pm 26$ & $86 \pm 10$ \\
\hline Per unit BM $\left(\mathrm{g} \cdot \mathrm{kg}^{-1} \cdot \mathrm{day}^{-1}\right)$ & $1.6 \pm 0.5$ & $1.4 \pm 0.6$ & $1.7 \pm 0.5$ & $1.5 \pm 0.5$ & $1.5 \pm 0.2$ \\
\hline Total protein energy ratio (\%) & $17 \pm 6$ & $16 \pm 4$ & $19 \pm 6$ & $17 \pm 4$ & $16 \pm 1$ \\
\hline \multicolumn{6}{|c|}{ Carbohydrate } \\
\hline Per day $\left(\mathrm{g} \cdot \mathrm{day}^{-1}\right)$ & $337 \pm 109$ & $321 \pm 76$ & $281 \pm 51$ & $314 \pm 97$ & $318 \pm 24$ \\
\hline Per unit BM $\left(\mathrm{g} \cdot \mathrm{kg}^{-1} \cdot \mathrm{day}^{-1}\right)$ & $6.0 \pm 2.3$ & $5.6 \pm 1.6$ & $5.0 \pm 1.3$ & $5.5 \pm 2.0$ & $5.6 \pm 0.4$ \\
\hline Of which are sugars $\left(\mathrm{g} \cdot \mathrm{day}^{-1}\right)$ & $155 \pm 71$ & $150 \pm 53$ & $103 \pm 38$ & $109 \pm 56$ & $136 \pm 24$ \\
\hline Total carbohydrate energy ratio (\%) & $55 \pm 7$ & $58 \pm 8$ & $49 \pm 7$ & $55 \pm 8$ & $55 \pm 3$ \\
\hline \multicolumn{6}{|c|}{ Fats } \\
\hline Per day $\left(\mathrm{g} \cdot \mathrm{day}^{-1}\right)$ & $73 \pm 24$ & $66 \pm 26$ & $80 \pm 19$ & $66 \pm 18$ & $70 \pm 7$ \\
\hline Per unit BM $\left(\mathrm{g} \cdot \mathrm{kg}^{-1} \cdot \mathrm{day}^{-1}\right)$ & $1.3 \pm 0.4$ & $1.1 \pm 0.5$ & $1.4 \pm 0.3$ & $1.1 \pm .0 .2$ & $1.2 \pm 0.1$ \\
\hline Of which are saturates $\left(\mathrm{g} \cdot \mathrm{day}^{-1}\right)$ & $28 \pm 11$ & $26 \pm 10$ & $27 \pm 7$ & $21 \pm 8$ & $26 \pm 3$ \\
\hline Total fats energy ratio $(\%)$ & $28 \pm 6$ & $27 \pm 8$ & $33 \pm 6$ & $28 \pm 6$ & $29 \pm 2$ \\
\hline
\end{tabular}

Table 2. Mean macronutrient intakes of adolescent soccer player's diets broken down by type of activity day (mean $\pm S D$ ). 


\subsection{Energy Balance}

Mean daily energy intake (9395 $\pm 1344 \mathrm{~kJ})$ was significantly lower than mean daily energy expenditure $(10679 \pm 1026 \mathrm{~kJ})(p<0.05)$. This resulted in a mean daily energy deficit of $-1302 \pm 1662 \mathrm{~kJ}$.

\subsection{Energy Cost of Activities}

Figure 1 illustrates the mean daily energy intake and expenditure data based on the type of training day. A significant difference was observed between mean energy intake and energy expenditure on heavy training days $(-2114 \pm 2257 \mathrm{~kJ})(p<0.05)$ and match day $(-2278 \pm 2307 \mathrm{~kJ})$ $(p<0.05)$. Although an energy deficit was also observed on a moderate training day $(-1034 \pm 2022 \mathrm{~kJ})$ this was not statistically significant $(p=0.14)$. Rest day was the only exception which identified a mean positive energy balance $(640 \pm 1197 \mathrm{~kJ})$; yet this this value was similar to energy expenditure $(p=0.125)$. The ratio of mean energy intake to mean energy expenditure was $89 \% \pm 16 \%$.

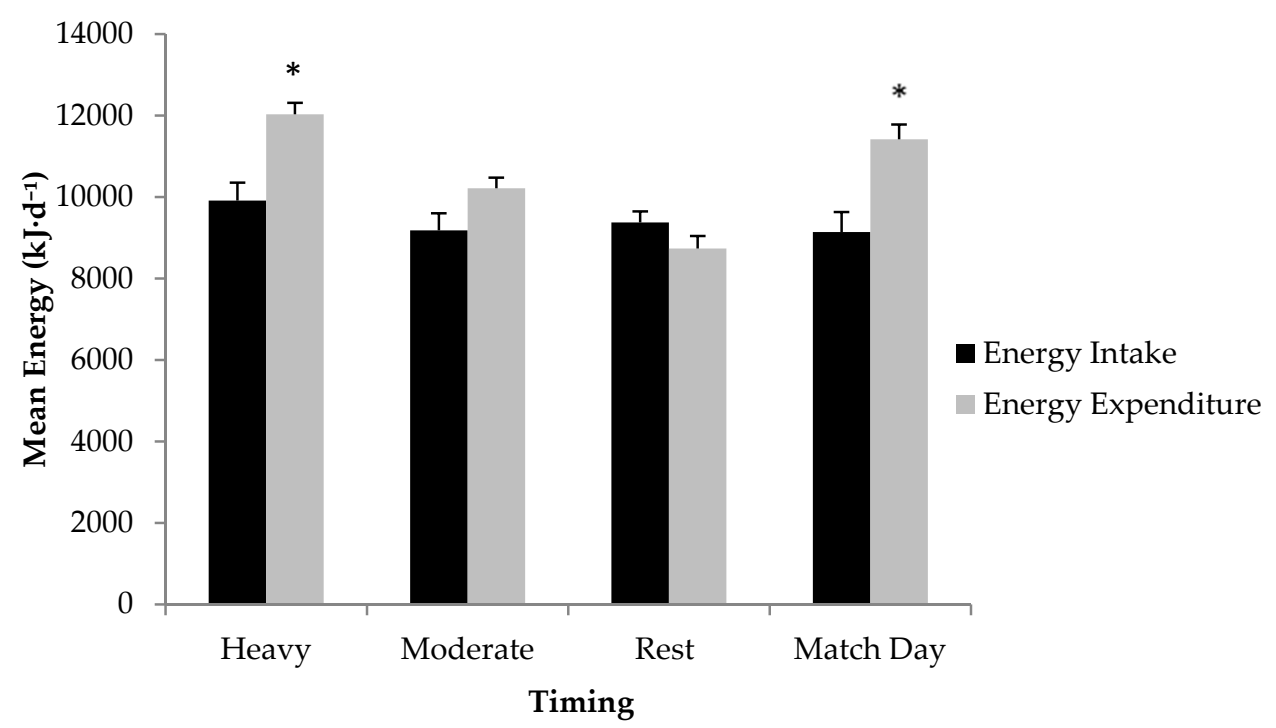

Figure 1. Mean Energy Intake (kJ) compared to Mean Energy Expenditure (kJ) for type of training. * Significant difference between mean energy intake and mean energy expenditure at the corresponding time-point at $p<0.05$ level.

The ANOVA revealed a significant main effect $(F(3,27)=6.682, p<0.01)$, with post hoc comparisons identifying significant differences between heavy training days and rest day $(-2755 \pm 745 \mathrm{~kJ} ; p<0.05)$, and also between a match day and rest day $(-2918 \pm 745 \mathrm{~kJ} ; p<0.01)$.

\section{Discussion}

The primary aim of the study was to assess energy balance in male adolescent academy-level soccer players. The findings demonstrate that over a seven day period players were in a negative energy balance, with energy intake being insufficient to meet the demands of training and competition. Mean daily energy intake was significantly lower than mean daily energy expenditure, providing a daily energy deficit. Additionally, type of training had a direct impact on the degree of energy deficit, highlighting that heavy training days and match days to be a particular threat to energy balance. Such information is likely of use to practitioners and players who should consider adjusting energy intake accordingly.

This is the first study to utilize accelerometry to assess energy expenditure, whilst accounting for energy intake during the same competitive week in adolescent academy-level soccer players 
competing in the UK. While magnitudes of deficits differ, evidence of negative energy balance reflects observations from similar populations competing outside of the UK [18-22]. In an attempt to quantify the magnitude of the mean energy deficit $\left(-1302 \pm 1662 \mathrm{~kJ} \cdot\right.$ day $\left.^{-1}\right)$, the findings of the present study provided a considerably lower deficit when compared to previous authors (e.g., $-3726 \pm 3073 \mathrm{~kJ} \cdot \mathrm{day}^{-1}[18] ;-3299 \pm 729 \mathrm{~kJ} \cdot$ day $^{-1}$ [23]). However caution must be exercised when attempting to apply direct comparisons due to methodological differences between study designs [38] and the absence of post body mass measurement. The greater deficit in the previous studies may be inflated due to using an estimated method of measuring energy expenditure; $14,445 \pm 1089 \mathrm{~kJ} \cdot$ day $^{-1}$ [18] and 15,148 $\pm 255 \mathrm{~kJ} \cdot$ day $^{-1}$ [23], in comparison to the current study's findings $\left(10,679 \pm 1026 \mathrm{~kJ} \cdot\right.$ day $\left.^{-1}\right)$, which used accelerometry as a more sensitive measure of energy expenditure.

To contextualize the energy deficit $\left(-1302 \pm 1662 \mathrm{~kJ} \cdot \mathrm{day}^{-1}\right)$ in relation to weight loss, this would equate to a mean weekly weight loss of $0.04 \pm 0.05 \mathrm{~kg}$ per player, using previously published equations [39]. Energy deficit coinciding with heavy training over a sustained period may cause detriments to health, impacting on optimal growth and development [11,40], in addition to performance detriments and increased risk of injury [41]. However due to external factors, participants were unavailable for body mass measurement during the immediate post-data collection period to determine if weight loss was evident, therefore energy deficit results should be interpreted with caution.

Information is lacking in the literature to determine where the greatest energy deficits are occurring throughout the week. Although studies outline mean energy expenditure values [18-22], these studies do not provide a breakdown of the difference between days. Within the current study a significant weekly deficit was observed, however only heavy training $(-2114 \pm 2257 \mathrm{~kJ})$ $(p<0.05)$ and match day $(-2278 \pm 2307 \mathrm{~kJ})(p<0.05)$ induced a significant energy deficit relative to energy expenditure. The deficits identified may have implications as Wang et al. [42] proposed a difference in energy intake of $461-691 \mathrm{~kJ} \cdot \mathrm{day}^{-1}$ to be clinically meaningful in a weight loss context. However, this could not be confirmed due to the inability to measure post-data collection body mass. In addition macronutrient intake was not significantly different between days. Findings may suggest that macronutrient consumption and total energy intake is relatively stable across the week, therefore the issue is that players are not adjusting intake to account for the intensity of training. This finding supports previous research, albeit in Professional Rugby League, whereby players' energy intake was not adjusted for type of training day, in addition, energy derived from carbohydrate remained stable throughout the week [43]. Recommendations of periodized nutritional intake may be advised to account for training intensity and volume [44], reflecting energy intake with the type of training day, either increasing or decreasing total consumption accordingly, to ensure a slight positive energy balance is achieved to not only optimize performance [11] but to sustain optimal growth and development $[9,10]$.

Burke et al. [45] proposes $5-7 \mathrm{~g} \cdot \mathrm{kg}^{-1} \cdot \mathrm{day}^{-1}$ for moderate training, increasing to $7-10 \mathrm{~g} \cdot \mathrm{kg}^{-1} \cdot \mathrm{day}^{-1}$ for intensive training. The current study's mean daily carbohydrate intake finding of $55 \% \pm 3 \%$, equating to $5.6 \pm 0.4 \mathrm{~g} \cdot \mathrm{kg}^{-1} \cdot \mathrm{day}^{-1}$, comprised mainly of starchy foods such as breads, cereals and pasta, demonstrate carbohydrate contribution to total daily energy intake to likely be sub-optimal, especially during heavy training sessions and match days (Table 2). This finding supports previous published research within this population with carbohydrate intake ranging from $45 \%$ to $56 \%[18-23,46]$. Diets high in carbohydrate enable an increased muscle glycogen concentration, subsequently delaying the onset of fatigue and sustaining performance levels $[47,48]$. However, it is also acknowledged that training with low carbohydrate availability may augment adaptive responses to exercise training $[49,50]$. Soccer specific studies have identified optimal carbohydrate intake to improve total match distance [51] and ability to perform at high-intensity [52]. However, chronic periods of sub-optimal energy intake, derived from inadequate carbohydrate 
consumption, coinciding with sustain periods of high training volumes may impair growth and development and effect performance levels [11,40,41].

Proteins are essential in recovery and to support gains in lean mass [53] and maintenance following muscle damaging exercise [54]. In the limited amount of nitrogen balance studies in adolescent soccer players, a recommendation of $1.4-1.7 \mathrm{~g} \cdot \mathrm{kg}^{-1} \cdot$ day $^{-1}$ [22], has been suggested which aligns with adult counterparts $\left(1.2-1.7 \mathrm{~g} \cdot \mathrm{kg}^{-1}\right.$. day $\left.{ }^{-1}\right)[53,55]$. The current study's findings of $1.5 \pm 0.2 \mathrm{~g} \cdot \mathrm{kg}^{-1}$. day ${ }^{-1}$ proposes protein intake is within the recommended range to optimize recovery and development, which was consumed mostly from poultry and dairy foods. This finding is not surprising with previous research reporting young athletes demonstrate adequate protein intakes, despite being in negative energy balance [56]. Optimal protein intake provides essential amino acids to support growth and development of lean body mass [11]. However, whilst acknowledging adequate protein intakes may be achieved with sub-optional energy intake, caution is required, as protein may be used as a substrate for energy, impacting on the ability to synthesize lean tissue.

Younger athletes have a greater reliance on fat as a fuel source during exercise [57], however there is currently no data recommending adolescent athletes consume a higher fat intake than adults. Given the high-intensity nature of soccer, fat recommendations are based upon facilitating carbohydrate intake, as opposed to contribution for energy metabolism [15]. Soccer-specific research suggests a fat intake of $<30 \%$ [15]. Studies assessing fat intake in male adolescent academy soccer players have reported intakes of $29 \%-38 \%$ [18-23,46], which are borderline or above recommendations. The current study's mean fat intake $(29 \% \pm 2 \%)$ may explain the limited consumption of optimal levels of carbohydrate, due to fat intake approaching the top limit of recommended consumption. Furthermore the quality of fats is important to consider with recommendations of $<10 \%$ of total energy intake derived from saturated fatty acids [38]. However, the current study found saturated fat values of $26 \% \pm 3 \%$. Considering the significant energy deficit within the current sample of players as well as recognizing recent research reporting utilization of fat as a fuel source to spare glycogen depletion [49,50], albeit equivocal, a reduction in fat intake may not be advisable. Moreover a reduction in saturated fatty acids may provide opportunity for consumption of unsaturated fats or higher intakes of carbohydrate, especially on match day to sustain performance levels.

It is acknowledged that all methods of measuring dietary intake have inherent limitations and may be affected by errors of precision and validity [58]. However, the current study is the first to adopt the combined method of a self-report weighed food diary, supplemented with daily 24-h recall, which has previously been validated in male adolescent academy-level soccer players [27] and other adolescent populations engaged in regular exercise [59]. The current study utilized the combined method and applied the correction equation to adjust energy intake data to accommodate for a slight under-reporting bias, which has been previously established within this population [27]. The current study also represents high ecological validity through the use of a free-living experimental design. Previous studies which have assessed energy intake and expenditure within formalized training centers $[21,46]$ may increase internal validity exerting greater control, but exclude influences of habitual family and school environment. Furthermore, whilst it is accepted that the data collection period may only provide a limited insight in to a 9 month long competitive season, a seven day energy intake collection period used within the current study is seen as optimal to increase reliability and validity whilst minimizing the burden of longitudinal collection periods [28]. In addition, the incorporation of the EPPP [26] stipulating compulsory training volumes of $20 \mathrm{~h}$ per week for academy soccer players ensure that there is little differentiation in training volume within the competitive periodization phase.

Measures of energy expenditure are diverse in the literature [18-23,46], with some studies failing to produce a quantification of energy cost whilst attempting to provide conclusions of optimal dietary practices [19]. The inconsistent approaches provide difficulties in accurately comparing the energy demands placed upon adolescent academy soccer players. Techniques such as doubly-labelled water 
and indirect calorimetry, although accurate [24], are complex, expensive and not applicable to a habitual setting. The current study utilized accelerometers, which have been demonstrated to elicit valid and reliable measures of physical activity and sedentary time in youth [25], providing an objective quantification of energy expenditure within a free-living environment. However, whilst it is accepted that energy expenditure measured by accelerometry produces high correlation with indirect calorimetry $[31,60]$, there is no absolute agreement, therefore limitations do need to be acknowledged when adopting such methods.

\section{Conclusions}

In conclusion, over a seven day period male adolescent academy-level soccer players were in a negative energy balance. This may have longer term implications impacting on the ability to sustain the demands of training and competition as well as maintaining optimal growth and development. In particular, heavy training and match days are of concern, with players not adjusting energy intake to combat the increased energy cost. Findings support previous research from outside of the UK, although demonstrating a lower, yet significant, mean daily energy deficit. Further interventions and education on nutritional strategies for academy soccer players should be considered relative to training and match play requirements to prevent detriments to optimal growth, development and performance.

Acknowledgments: The authors would like to acknowledge Sunderland AFC in their assistance in recruiting participants. We would also like to thank the soccer players for taking the time to participate in this study.

Author Contributions: The lead author Marc Briggs performed the experiment and analyzed the data. Emma Cockburn assisted in the data analysis and all authors contributed to writing the paper.

Conflicts of Interest: The authors declare no conflict of interest.

\section{References}

1. Stolen, T.; Chamari, K.; Castagna, C.; Wisloff, U. Physiology of soccer. Sports Med. 2005, 35, 501-512. [CrossRef] [PubMed]

2. Goto, H.; Morris, J.G.; Nevill, M.E. Motion analysis of U11 to U16 elite English Premier League Academy players. J. Sport Sci. 2015, 33, 1248-1258. [CrossRef] [PubMed]

3. Buchheit, M.; Mendez-Villanueva, A.; Simpson, B.M.; Bourdon, P.C. Match Running Performance and Fitness in Youth Soccer. Int. J. Sports Med. 2010, 31, 818-825. [CrossRef] [PubMed]

4. Helgerud, J.; Engen, L.C.; Wisloff, U.; Hoff, J. Aerobic endurance training improves soccer performance. Med. Sci. Sports Exerc. 2001, 11, 1925-1931. [CrossRef]

5. Russell, M.; Sparkes, W.; Northeast, J.; Kilduff, L.P. Responses to a $120 \mathrm{~m}$ reserve team soccer match: A case study focusing on the demands of extra time. J. Sport Sci. 2015. [CrossRef] [PubMed]

6. Russell, M.; Sparkes, W.; Northeast, J.; Cook, C.J.; Love, T.D.; Bracken, R.M.; Kilduff, L.P. Changes in acceleration and deceleration capacity throughout professional soccer match-play. J. Strength Cond. Res. 2014. [CrossRef] [PubMed]

7. Bangsbo, J.; Mohr, M.; Krustrup, P. Physical and metabolic demands of training and match-play in the elite football player. J. Sports Sci. 2006, 24, 665-674. [CrossRef] [PubMed]

8. Bar-Or, O. Nutrition for child and adolescent athletes. Sports Sci. Exch. 2000, 13, 2.

9. Spear, BA. Adolescent growth and development. J. Am. Diet Assoc. 2002, 3, S23-S29. [CrossRef]

10. Giovannini, M.; Agostoni, C.; Gianni, M.; Bernardo, L.; Riva, E. Adolescence: Macronutrient needs. Eur. J. Clin. Nutr. 2000, 54 (Suppl. 1), S7-S10. [CrossRef] [PubMed]

11. Petrie, H.J.; Stover, E.A.; Horswill, C.A. Nutritional concerns for the child and adolescent competitor. Nutrition 2004, 20, 620-631. [CrossRef] [PubMed]

12. Martin, L.; Lambeth, A.; Scott, D. Nutritional practices of national female soccer players: Analysis and recommendations. J. Sports Sci. Med. 2006, 5, 130-137. [PubMed]

13. Maughan, R.J. Energy and macronutrient intakes of professional football (soccer) players. Br. J. Sports Med. 1997, 31, 45-47. [CrossRef] [PubMed] 
14. Reilly, T. Physiological aspects of soccer. Biol. Sport 1994, 11, 3-20.

15. Clark, K. Nutritional guidance to soccer players for training and competition. J. Sports Sci. 1994, 12, S43-S50. [PubMed]

16. Hargreaves, M. Carbohydrate and lipid requirements of soccer. J. Sports Sci. 1994, 12, S13-S16. [PubMed]

17. Caldarone, G.; Teanquilli, C.; Giampietro, M. Assessment of the nutritional state of top level football players. In Sports Medicine Applied to Football; Santilli, G., Ed.; CONI: Rome, Italy, 1990; pp. 133-141.

18. Caccialanza, R.; Cameletti, B.; Cavallaro, G. Nutritional intake of young Italian high-level soccer players: Under-reporting is the essential outcome. J. Sports Sci. Med. 2007, 6, 538-542.

19. Ruiz, F.; Irazusta, A.; Casis, L.; Gil, J. Nutritional intake in soccer players of different ages. J. Sports Sci. 2005, 23, 235-242. [CrossRef] [PubMed]

20. Iglesias-Gutierrez, E.; Garcia-Roves, P.M.; Rodriguez, C.; Braga, S.; Garcia-Zapico, P.; Patterson, A.M. Food Habits and nutritional status assessment of adolescent soccer players: A necessary and accurate approach. Can. J. Appl. Physiol. 2005, 30, 18-32. [CrossRef] [PubMed]

21. Leblanc, J.C.; Le Gall, F.; Grandjean, V.; Verger, P. Nutritional intake of French soccer players at the Clairefontaine training center. Int. J. Sports Nutr. Exerc. Metab. 2002, 12, 268-280.

22. Boisseau, N.; Le Creff, C.; Loyens, M.; Poortmans, J.R. Protein intake and nitrogen balance in male non-active adolescents and soccer players. Eur. J. Appl. Physiol. 2002, 88, 288-293. [PubMed]

23. Russell, M.; Pennock, A. Dietary analysis of young professional soccer players in 1 week during the competitive season. J. Strength Cond. Res. 2011, 25, 1-8. [CrossRef] [PubMed]

24. Plasqui, G.; Bonomi, A.G.; Westerterp, K.R. Daily physical activity assessment with accelerometers: New insights and validation studies. Obes. Rev. 2013, 14, 451-462. [CrossRef] [PubMed]

25. De Vries, S.I.; Bakker, I.; Hopman-Rock, M.; Hirasing, R.A.; Van Mechelen, W. Clinimetric review of motion sensors in children and adolescents. J. Clin. Epidemiol. 2006, 59, 670-680. [CrossRef] [PubMed]

26. Premierleague.com. Available online: http://www.premierleague.com/content/premierleague/en-gb/ youth/elite-player-performance-plan.html (accessed on 3 July 2015).

27. Briggs, M.A.; Rumbold, P.L.S.; Cockburn, E.; Russell, M.; Stevenson, E.J. Agreement between two methods of dietary data collection in male adolescent academy-level soccer players. Nutrients 2015, 7, 5948-5960. [CrossRef] [PubMed]

28. Bingham, S. The dietary assessment of individuals: Methods, accuracy, new techniques and recommendations. Nutr. Abstr. Rev. 1987, 57, 705-741.

29. Ashley, J.M.; Bovee, V.H. Dietary intake: Recording and analyzing. In Obesity: Etiology, Assessment, Treatment and Prevention; Andersen, R.E., Ed.; Human Kinetics: Champaign, IL, USA, 2007; pp. 99-110.

30. Deakin, V. Measuring nutritional status of athletes: Clinical and research perspectives. In Clinical Sports Nutrition; Burke, L., Deakin, V., Eds.; McGraw-Hill: Sydney, Australia, 2000; pp. 30-68.

31. Jarrett, H.; Fitzgerald, L.; Routen, A.C. Interinstrument Reliability of the ActiGraph GT3X+ Ambulatory Activity Monitor During Free-Living Conditions in Adults. J. Phys. Act. Health. 2015, 12, 382-387. [CrossRef] [PubMed]

32. Evenson, K.R.; Cattellier, D.; Gill, K.; Ondrak, K.; McMurray, R.G. Calibration of two objective measures of physical activity for children. J. Sports Sci. 2008, 26, 1557-1565. [CrossRef] [PubMed]

33. Mattocks, C.; Leary, S.; Ness, A. Calibration of an accelerometer during free-living activities in children. Int. J. Pediatr. Obes. 2007, 2, 218-226. [CrossRef] [PubMed]

34. Treuth, M.S.; Schmitz, K.; Catellier, D.J. Defining accelerometer thresholds for activity intensities in adolescent girls. Med. Sci. Sports Exerc. 2004, 36, 1259-1266. [PubMed]

35. Trost, S.G.; Loprinzi, P.D.; Moore, R.; Pfeiffer, K.A. Comparison of accelerometer cut points for predicting activity intensity in youth. Methodol. Adv. 2011, 43, 1360-1368. [CrossRef] [PubMed]

36. Ridley, K.; Ainsworth, B.E.; Olds, T.S. Development of a compendium of energy expenditures for youth. Int. J. Behav. Nutr. Phys. Act. 2008, 5, 45-52. [CrossRef] [PubMed]

37. Schofield, W.N. Predicting basal metabolic rate, new standards and review of previous work. Hum. Nutr. Clin. Nutr. 1985, 39 (Suppl. 1), 5-41.

38. Garcia-Roves, P.M.; Garcia-Zapico, P.; Patterson, A.M.; Iglesias-Gutierrez, E. Nutrient intake and food habits of soccer players: Analyzing the correlates of eating patterns. Nutrients 2014, 6, 2697-2717. [CrossRef] [PubMed] 
39. McArdle, W.D.; Katch, F.I.; Katch, V.L. Exercise Physiology; Lippincott, Williams and Wilkins: Philadelphia, PA, USA, 1999.

40. Meyer, F.; O'Conner, H.; Shirreffs, S.M. Nutrition for the young athlete. J. Sport Sci. 2007, $25,73-82$. [CrossRef] [PubMed]

41. Thompson, J.L. Energy balance in young athletes. Int. J. Sport Nutr. 1998, 8, 160-174. [PubMed]

42. Wang, Y.C.; Gortmaker, S.L.; Sobol, A.M.; Kuntz, K.M. Estimating the energy gap among US children: A counterfactual approach. Pediatrics 2006, 118, 1721-1733. [CrossRef] [PubMed]

43. Tooley, E.; Bitcon, M.; Briggs, M.; West, D.; Russell, M. Estimates of Energy Intake and Expenditure in Professional Rugby League Players. Int. J. Sports Sci. Coach. 2015, 10, 2-3. [CrossRef]

44. Burke, L.M. Fueling strategies to optimize performance: Training high or training low. Scand. J. Med. Sci. Sports 2010, 20, 48-58. [CrossRef] [PubMed]

45. Burke, L.M.; Loucks, A.B.; Broad, N. Energy and carbohydrate for training and recovery. J. Sports Sci. 2006, 24, 675-685. [CrossRef] [PubMed]

46. Rico-Sanz, J. Body composition and nutritional assessments in soccer. Int. J. Sports Nutr. 1998, 8, $113-123$.

47. Alghannam, A.F.; Jedrzejewski, D.; Tweddle, M.G.; Gribble, H.; Bilzon, J.; Thompson, D.; Tsintzas, K.; Betts, J.A. Impact of Muscle Glycogen Availability on the Capacity for Repeated Exercise in Man. Med. Sci. Sports Exerc. 2015. [CrossRef] [PubMed]

48. Burke, L.M.; Hawley, J.A.; Wong, S.H.; Jeukendrup, A.E. Carbohydrates for training and competition. J. Sports Sci. 2011, 29, S17-S27. [CrossRef] [PubMed]

49. Hansen, A.K.; Fischer, C.P.; Plomgaard, P.; Anderson, J.L.; Saltin, B.; Pedersen, B.K. Skeletal muscle adaptation: Training twice every second day vs. training once daily. J. Appl. Physiol. 2005, 98, 93-99. [CrossRef] [PubMed]

50. Yeo, W.K.; Paton, C.D.; Garnham, A.P.; Burke, L.M.; Carey, A.L.; Hawley, J.A. Skeletal muscle adaptation and performance responses to once a day verses twices a day endurance training regimens. J. Appl. Physiol. 2008, 105, 1462-1470. [CrossRef] [PubMed]

51. Souglis, A.G.; Chryssanthopoulos, C.I.; Travlos, A.K.; Zorzou, A.E.; Gissis, I.T.; Papadopoulos, C.N.; Sotiropoulos, A.A. The effect of high vs. low carbohydrate diets on distances covered in soccer. J. Strength Cond. Res. 2013, 27, 2235-2247. [CrossRef] [PubMed]

52. Kingsley, M.; Penas-Ruiz, C.; Terry, C.; Russell, M. Effects of carbohydrate-hydration strategies on glucose metabolism, sprint performance and hydration during a soccer match simulation in recreational players. J. Sci. Med. Sport 2014, 17, 239-243. [CrossRef] [PubMed]

53. Tipton, K.D.; Wolfe, R.R. Protein and amino acids for athletes. J. Sports Sci. 2004, 22, 65-79. [CrossRef] [PubMed]

54. Tipton, K.D.; Elliott, T.A.; Cree, M.G.; Aarsland, A.A.; Sanford, A.P.; Wolfe, R.R. Stimulation of net muscle protein synthesis by whey protein ingestion before and after exercise. Am. J. Physiol. Endocrinol. Metab. 2007, 1, E71-E76. [CrossRef] [PubMed]

55. Lemon, P.W.R. Protein requirements of soccer. J. Sports Sci. 1994, 12, S17-S22. [PubMed]

56. Bass, S.; Inge, K. Nutrition for special populations: Children and young athletes. In Clinical Sports Nutrition; Burke, L.M., Deakin, V., Eds.; McGraw-Hill: Sydney, Australia, 2006; pp. 589-632.

57. Bar-Or, O. Nutritional considerations for the child athlete. Can. J. Appl. Physiol. 2001, 26, S186-S191. [CrossRef]

58. Black, A.E. Dietary assessment for sports dietetics. Nutr. Bull. 2001, 26, 29-42. [CrossRef]

59. Rumbold, P.L.S.; St Clair Gibson, A.; Stevenson, E.; Dodd-Reynolds, C.J. Agreement between two methods of dietary data collection in female adolescent netball players. Appetite 2011, 57, 443-447. [CrossRef] [PubMed]

60. McMinn, D.; Acharya, R.; Rowe, D.A.; Gray, S.R.; Allan, J.L. Measuring activity energy expenditure: Accuracy of the GT3X+ and Actiheart monitors. Int. J. Exerc. Sci. 2013, 6, 217-229.

(C) 2015 by the authors; licensee MDPI, Basel, Switzerland. This article is an open access article distributed under the terms and conditions of the Creative Commons by Attribution (CC-BY) license (http://creativecommons.org/licenses/by/4.0/). 